\title{
Analisis Dan Efisiensi Daya Instalasi Penerangan Jalan Umum Menggunakan Solar Cell di Kabupaten Lamongan
}

\author{
Nahdia Rupawanti BR *) \\ ${ }^{*}$ Program Studi Teknik Elektro, Fakultas Teknik, Universitas Islam Lamongan \\ E-mail : nahdiarupawanti@gmail.com
}

\begin{abstract}
Abstrak
Penerangan Jalan umum dengan menggunakan tenaga surya merupakan sebuah alternatif yang murah dan hemat untuk digunakan sebagai sumber listrik penerangan karena menggunakan sumber energi gratis dan tak terbatas dari alam, yaitu energi matahari. Pada sistem penerangan jalan raya di Kecamatan Mantup Kabupaten Lamongan menggunakan solar cell sebesar 150 wp dan beban lampu 40 w. Ketika cuaca cerah dapat menghasilkan daya 645,189 wh. Jika dalam keadaan panel surya tidak bisa menerima cahaya, baterai masih mempunyai cadangan daya 186 wh. Sedangkan untuk penerangan lampu jalan menghasilkan luminasi sebesar $15,7 \mathrm{~cd} / \mathrm{m}^{2}$ dan iluminasi sebesar 63,2 lux. Efisiensi daya dari panel modul solar sel sebesar $18 \%$ ditentukan oleh posisi kemiringan dari panel solar sel dan intensitas cahaya matahari. Semakin tinggi intensitas cahaya matahari semakin tinggi efisiensi keluaran modul solar sel. Sehingga pada jam 12.00 siang tegangan modul meningkat hingga $20 \mathrm{~V}$ sedangkan arus 4.0 A. Untuk mengoptimalkan solar cell pada efisensi penel surya adalah dengan cara memasang sebuah konsentrator optik pada sistem panel solar cell sehingga dapat meningkatkan intensitas cahaya 6-400 kali matahari dan meningkatkan efisiensinya sebesar $15 \%$.
\end{abstract}

Kata Kunci : penerangan jalan, solar cell, efisiensi

\section{PENDAHULUAN}

Salah satu pemakaian listrik yang banyak digunakan masyarakat saat ini adalah sebagai sumber penerangan. Semakin meningkatnya tingkat mobilitas masyarakat membuat semua kegiatan memerlukan penerangan. Salah satu bagian yang penting dan memerlukan penerangan adalah jalan raya atau jalan umum.

Penerangan jalan umum adalah lampu penerangan yang bersifat publik (untuk kepentingan bersama) dan biasanya sengaja dipasang diruas jalan maupun di tempat-tempat tertentu seperti taman, dan tempat umum lainnya. Penerangan Jalan Umum (PJU) dalam bahasa Inggrisnya Street Lighting atau Road Lighting adalah suatu sumber cahaya yang dipasang pada samping jalan, yang dinyalakan pada setiap malam. Penerangan Jalan umum dengan menggunakan tenaga surya merupakan sebuah alternatif yang murah dan hemat untuk digunakan sebagai sumber listrik penerangan karena menggunakan sumber energi gratis dan tak terbatas dari alam yaitu energi matahari. Lampu Jalan Tenaga Surya ( PJU Tenaga Surya) menggunakan Modul/Panel Surya dengan lifetime hingga 25 tahun yang berfungsi menerima cahaya (sinar) matahari yang kemudian diubah menjadi listrik melalui proses photovoltaic. Lampu ini secara otomatis dapat mulai menyala pada sore hari dan padam pada pagi hari dengan perawatan yang mudah dan efisien selama bertahun tahun. Pemasangan instalasi Penerangan Jalan Umum tidak terlepas dari permasalahan yang sering muncul di lapangan antara lain cahaya yang

\section{Latar Belakang}

tidak merata, pemakaian material yang tidak sesuai, pemasangan tiang lampu yang tidak rapih, dan lainlain.

Untuk mengatasi masalah-masalah tersebut di atas, dalam pelaksanaan pembangunan Penerangan Jalan Umum diperlukan perencanaan yang baik, sehingga pemasangan lampu penerangan jalan umum tersebut mempunyai efisiensi yang tinggi, mempunyai kuat penerangan yang cukup dan biaya operasional yang murah. Salah satu cara untuk memperoleh tujuan perencanaan tersebut adalah perhitungan yang tepat tentang lokasi proyek sesuai dengan kebutuhan penerangan dan pemilihan material yang tepat untuk proses instalasi PJU.

\footnotetext{
Rumusan Masalah

a. Berdasarkan latar belakang masalah di atas, maka penulis merumuskan masalah sebagai berikut:

b. Bagaimana efisiensi daya solar cell di Kabupaten Lamongan?

c. Bagaimana cara optimalisasi pada efisiensi penerangan jalan umum menggunakan solar cell?
}

\section{METODOLOGI}

Metode pelaksanaan penelitian menggunakan kajian literatur, pengumpulan datat dan observasi lapangan terhadap bagian-bagian dari sistem sel surya yang digunakan sebagai lampu jalan. 


\section{- Modul Surya}

Besar fill factor sel surya :

$F F=\frac{V_{m \times I_{m}}}{V_{o c \times I_{s c}}}$

Maka efisensi sel surya adalah

$$
\begin{aligned}
& \eta=\frac{P_{o u t}}{P_{\text {in }}}=\frac{V_{o c \times I_{s c \times F F}}}{F F} \\
& \eta=\frac{V_{m \times I_{m}}}{S \times F} \ldots \ldots \ldots \ldots \ldots \ldots \ldots \ldots \ldots \ldots \ldots \ldots \ldots \ldots
\end{aligned}
$$

Dimana: $\mathrm{FF}=$ faktor pengisian/fill factor

$V_{m}=$ tegangan nominal panel surya (volt)

$I_{m}=$ arus nominal panel surya (volt)

$V_{o c}=$ tegangan open cicuit panel surya (volt)

$I_{s c}=$ arus short circuit panel surya (volt)

$\mathrm{F}=$ intensitas radiasi matahari yang diterima (watt $/ \mathrm{m} 2$ )

$\mathrm{S}=$ luas permukaan modul sel surya $(\mathrm{m} 2)$

untuk mencari jumlah sinar global yang datang dapat dihitung dengan mengalikan besarnya flux radiasi dengan lamanya penyinaran dalam satu hari.

Dirumuskan $:\left(\frac{\frac{w h}{m^{2}}}{\text { hari }}\right)=\sigma \cdot e \cdot T^{4} \cdot t_{s}$

dimana $: \mathrm{P}=$ Daya $($ watt $)$

$\mathrm{A}=\operatorname{luas}(\mathrm{m} 2)$

$\sigma=$ tetapan Stefan-Boltzmann $(5,67$ x $10-8$

watt/m2K4)

$e=$ koefisien emisivitas $(0-1)$

$T^{4}=$ suhu permukaan $(\mathrm{oK})$

$t_{s}=$ lamanya penyinaran (hours

Lamanya panel surya mendapatkan penyinaran

$t_{\text {modul }}=\frac{\text { jumlah sinar global }\left(\text { wh } / \mathrm{m}^{2} / \text { hari }\right)}{\text { maksimum sinar global }\left(\text { watt } / \mathrm{m}^{2} / \text { hari }\right)}$

$E_{\text {modul }}=P_{\text {nom }} \times t_{\text {modul }}$

$E_{\text {modul }}=P_{\text {nom }} \times \frac{\text { jumlah sinar global }\left(\text { wh } / \mathrm{m}^{2} / \text { hari }\right)}{\text { maksimum sinar global }\left(\text { watt } / \mathrm{m}^{2} / \text { hari }\right)}$

\section{Baterai}

Maka untuk menentukan total kapasitas baterai berdasarkan periode penyimpanan yang di inginkan sebagai berikut :

Dirumusakan $: t_{\text {beban }}=\frac{P_{\text {beban }}}{P_{\text {batrai }}}$

Dimana $: t_{\text {beban }}=$ waktu pemakaian baterai

$$
\begin{gathered}
\text { (Ah/Ampere.hour) } \\
P_{\text {beban }}=\text { daya lampu (volt) } \\
P_{\text {baterai }}=\text { daya baterai }
\end{gathered}
$$

\section{Solar Charge Controll}

Ukuran atau rating untuk alat pengontrol aliran masuk dan keluar dari aki ditentukan dalam satuan Ampere, yakni dengan rumus.

$i_{c c}=I_{s c} \times\left(100 \%+\eta_{\text {batrai }}\right)$ $i_{c c}=\frac{P_{\operatorname{maks}}}{F F \times V_{o c}} \times(100 \%+$

$\left.\eta_{\text {batrai }}\right)$

Dimana $: i_{c c}=$ arus rating solar charge controller

(ampere)

$P_{\text {maks }}=$ banyak panel surya $\mathrm{x}$ Pnom (watt)

\section{Daya Lampu}

Besar energi yang terpakai lampu PJU adalah besarnya daya lampu dikali dengan lamanya lampu menyala (beroperasi) adalah

$E_{\text {load }}=P_{\text {load }} \times t$

Dimana $: E_{\text {load }}=$ Energi yang terpakai $($ wh)

$P_{\text {load }}=$ Daya beban atau lampu (watt)

$\mathrm{T}=$ Lama pemakaian beban (jam)

\section{Pencahayaan Lampu}

Intensitas cahaya adalah fluks cahaya per satuan sudut ruang dalarn arah pancaran cahaya

$I=\frac{\emptyset}{w}$

Dimana :I = Intensitas cahaya (Candela/cd)

$\emptyset=$ Fluks cahaya dalam lumen $(\mathrm{lm})$

$\mathrm{W}=$ sudut ruang dalam steridian $(\mathrm{sr})$

Luminansi adalah fluks cahaya persatuan sudut ruang atau intensitas cahaya dari suatu permukaan per satuan luas.

$L=\frac{\phi}{w(A \cos \theta)}=\frac{I}{w(A \cos \theta)}=\frac{\phi}{r^{2} \cos \theta}$

Dimana $: \mathrm{L}=$ luminasi $\left(\mathrm{cd} / \mathrm{m}^{2}\right)$

$\mathrm{A}=$ Luas bidang $\left(\mathrm{m}^{2}\right)$

$\mathrm{R}=$ Jarak sumber cahaya ke sebuah titik (m)

$\theta=$ sudut antara sinar datang dengan garis

normal objek

lluminasi atau intensitas penerangan adalah kerapatan fluks cahaya yang mengenai suatu permukaaan.

$E=\frac{\phi}{A}=\frac{\phi_{g}}{r^{2}} \cos \theta=\frac{\phi_{g}}{h^{2}} \cos ^{3} \theta$

$\cos \alpha=\cos \theta=\frac{h}{r}$

Dimana : $\mathrm{E}=$ Intensitas penerangan/iluminasi (luk/lm/ $\mathrm{m}^{2}$ )

$\phi_{g}=$ Fluks cahaya dalam Lumen (lm)

$\mathrm{H}=$ tinggi cahaya ke permukaan tanah secara vertikal (m)

\section{Daya total lampu}

$P_{\text {total }}=P \times n \times$

$\cos \varphi$.

Dimana $: P_{\text {total }}$ : Daya lampu total $(\mathrm{W})$

P : Daya lampu (W)

$\mathrm{N}$ : Jumlah lampu per APP 
Daya Lampu dalam sehari

$P_{\text {hari }}=P_{\text {total }} \times t$

Dimana $: P_{\text {hari }}$ : Daya lampu total per hari (Kwh)

$P_{\text {total }}:$ Daya lampu total $(\mathrm{W})$

$\mathrm{t}$ : waktu nyala (jam)

\section{Flowchart Penelitian}

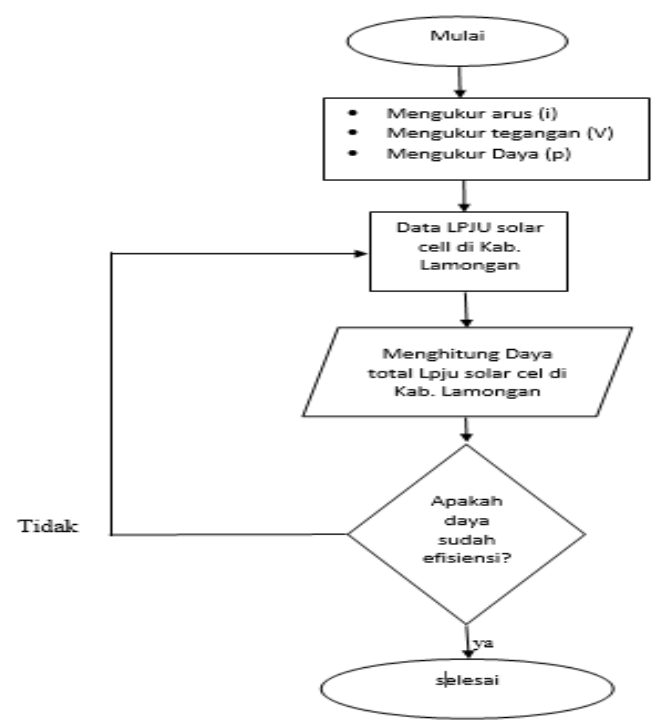

Gambar 6 diagram alir penelitian

\section{Solar Cell}

III. HASIL DAN PEMBAHASAN

Pada penelitian yang di lakukan pada tanggal 14 mei 2017 di jalan raya mantup dengan keadaaan cuaca terang pada jam $08.00 \mathrm{~s} / \mathrm{d} 16.00$ maka di dapat hasil seperti tabel berikut.

\begin{tabular}{ccc}
\multicolumn{3}{c}{ Tabel.1 pengukuran tegangan panel surya } \\
\hline Jam & $V_{\text {in }}$ & $I_{\text {in }}$ \\
\hline 08.00 & 12 & 0,1 \\
\hline 09.00 & 14 & 2,6 \\
\hline 10.00 & 16 & 3.8 \\
\hline 11.00 & 17 & 3,9 \\
\hline 12.00 & 20 & 4.0 \\
\hline 13.00 & 18 & 3,9 \\
\hline 14.00 & 16 & 3,7 \\
\hline 15.00 & 13 & 2,6 \\
\hline 16.00 & 12 & 2,4 \\
\hline
\end{tabular}

Maka kita harus mencari dahulu faktor pengisian dengan menggunakan persamaaan (3.1) yaitu :

$$
F F=\frac{V m \times I m}{V o c \times I s c}=\frac{40 \times 3,75}{48 \times 4,13}=0,76
$$

Luas permukaan panel surya

$$
\begin{aligned}
& =\left(1482 \mathrm{~mm}^{2} \times 670 \mathrm{~mm}^{2}\right) \\
& =992.940 \mathrm{~mm}^{2} \\
& =0,992940 \mathrm{~m}^{2}
\end{aligned}
$$

Dimana besar intensitas sinar global matahari yang diterima ketika radiasi dalam keadaan maksimum (S) sebesar $1000 \mathrm{watt} / \mathrm{m}^{2}$.

Menurut data Badan Meteorologi dan Klimatologi dan Geofisika (BMKG), suhu Kabupaten Lamongan yang terletak pada 651'54" - 723'06" LS dan 11233'45" - 11233'45" BT. berkisar antara $24^{\circ} \mathrm{C}$ $34^{\circ} \mathrm{C}$ ketika penyinaran berlangsung akan di peroleh besarnya jumlah sinar global, di mana e $=1, \mathrm{~T}=30^{\circ}$ $\mathrm{C}=303^{\circ} \mathrm{K}$, dengan lama penyinaran dari 08.00 $16.00=9$ jam adalah:

Jumlah Sinar Global

$$
\begin{gathered}
\left(\frac{\frac{w h}{m^{2}}}{\text { hari }}\right)=\sigma . e . T^{4} . s \\
=5,67 \times 10^{-8} \times 1 \times(303)^{4} \times 9
\end{gathered}
$$

Jumlah Sinar Global

$$
\left(\frac{w h / m^{2}}{h a r i}\right)=4301,26\left(w h / m^{2} / \text { hari }\right)
$$

Untuk mendapatkan lamanya panel surya mendapatkan sinar matahari $t_{\text {modul }}$, dimana maksimum sinar global sebesar $1000 \mathrm{watt} / \mathrm{m}^{2} /$ hari dengan persamaan (3.3) adalah :

$$
\begin{aligned}
& t_{\text {modul }}=\frac{\text { Jumlah sinar global }\left(\frac{\frac{w h}{m^{2}}}{\text { hari }}\right)}{\text { Maksimum sinar global }\left(\frac{\frac{w h}{m^{2}}}{\text { hari }}\right)} \\
&=\frac{4301,26}{1000} \\
& t_{\text {modul }}=4,30126 \mathrm{jam} \\
& E_{\text {modul }}=P_{\text {nom }} \times t_{\text {modul }} \\
&= 150 \times 4,30126 \\
&=645,189 \mathrm{wh}
\end{aligned}
$$

Jadi ketika cuaca keadaan cerah dalam sehari panel surya dapat menghasilkan daya 645,189 wh.

\section{Baterai}

Untuk mencari cadangan daya baterai untuk mengcover beban ketika panel surya tidak mendapatkan cahaya dalam sehari. Maka dapat di hitung menggunakan persamaan...

Daya baterai 


$$
\begin{gathered}
P_{\text {batrai }}=V . I \\
=33,3 \times 20 \mathrm{Ah} \\
=666 \mathrm{wh}
\end{gathered}
$$

Daya baterai yang di gunakan adalah 666 wh. Maka untuk menghitung cadangan beban dalam satu hari selam 12 jam sadalah dengan menggunakan perhitungan.

$$
\begin{aligned}
& t_{\text {baban }}=\frac{P_{\text {batrai }}}{P_{\text {beban }}} \\
& =\frac{666 \mathrm{wh}}{40 \mathrm{w}} \\
& =16 \mathrm{jam} 45 \text { menit }
\end{aligned}
$$

Dari perhitungan di atas mendapatkan hasil bahwa dalam keadaan baterai terisi penuh dapat menyalakan beban lampu hingga 16 jam 45 menit. Jika dalam sehari beban hanya menyala selama 12 jam dari jam $17.30 \mathrm{~s} / \mathrm{d} \quad 05.30$ maka baterai masih memiliki cadangan beban hingga 4 jam 45 menit. Untuk menghitung daya pada baterai dapat menggunakan persamaan rumus.

$$
\begin{gathered}
P_{\text {cadangan }}=P_{\text {batrai }}-\left(P_{\text {beban }} \times t_{\text {beban }}\right) \\
=666 \mathrm{wh}-(40 \mathrm{w} \times 12 \mathrm{jam}) \\
=666 \mathrm{wh}-(480 \mathrm{w}) \\
=186 \mathrm{wh}
\end{gathered}
$$

\section{Solar Charge Controller}

Ukuran atau rating untuk alat pengontrol aliran masuk dan keluar dari aki dalam satuan Ampere di hitung dengan persamaan (3.6) adalah:

$$
\begin{gathered}
i_{c c}=\frac{P_{\text {maks }}}{F F \times V_{o c}} \times(100 \%+90 \%) \\
=\frac{1 \times 150}{0,76 \times 48} \times(100 \%+90 \%) \\
i_{C C}=7,5 \text { ampere }
\end{gathered}
$$

\section{Lampu LED}

Pada kabupaten lamongan penggunaan dan pemasangan LPJU Solar Cell menggugunakan lampu 40 watt untuk penerangan jalan.

Tabel 2 spesifikasi lapu LED Solar Cell

$$
\text { Keterangan PJU solar cell }
$$

\begin{tabular}{cc}
\hline Jenis lampu & Lampu LED \\
\hline Daya & $40 \mathrm{watt}$ \\
\hline lumen & $5000 \mathrm{~lm}$ \\
\hline $\begin{array}{c}\text { Sudut kemiringan } \\
\text { ornamen }\end{array}$ & $10^{0}$ \\
\hline
\end{tabular}

Sedangkan besar energi yang dipakai lampu LED di hitung demgan persamaan (3.7) adalah:

$$
E_{\text {load }}=40 \mathrm{watt} \times 12 \frac{\mathrm{jam}}{\mathrm{hari}}=0,48 \mathrm{kwh} / \mathrm{jam}
$$

Untuk intensitas cahaya PJU solar cell di hitung dengan persamaan (3.8):

$$
I=\frac{\emptyset}{w}=\frac{5000}{4 \pi}=\frac{5000}{4 \times 3,14}=398,1 \mathrm{~cd}
$$

Untuk Luminasi lampu LED adalah di hitung dengan menggunakan persamaan (3.9):

$$
\begin{gathered}
L_{\text {rata-rata }}=\frac{398,1}{40 \cdot \cos 60^{0}}=19,9 \mathrm{~cd} / \mathrm{m}^{2} \\
L_{\text {maks }}=\frac{I}{r^{2} \cdot \cos \varphi}=\frac{398,1}{8^{2} \cdot \cos 10^{0}}=15,7 \mathrm{~cd} / \mathrm{m}^{2}
\end{gathered}
$$

Iluminasi (intensitas pencahayaan) LPJU solar cell dapat di hitung dengan menggunakan persamaan (3.10).

$$
\begin{gathered}
E_{\text {rata-rata }}=\frac{\emptyset}{A}=\frac{1485}{40}=37,1 \text { lux } \\
E_{\text {maks }}=\frac{\emptyset_{g}}{h^{2}} \cos ^{2} \alpha=\frac{1485}{8^{2}} \cos ^{3} 10^{0}=63,2 \text { lux }
\end{gathered}
$$

\section{Total Daya Lampu}

Jumlah lampu yang digunakan dalam LPJU Solar cell di Kecamatan Mantup adalah 70 titik. Dan semuanya menggunakan lampu LED 40 watt. Untuk perhitungan total daya lampu yang di pakai dalam penerangan jalan umum menggunakan solar cell maka bisa menggunakan persamaan.

Daya total Lampu penerangan jalan umum Solar Cell.

$$
\begin{aligned}
P_{\text {total }} & =40 \times 70 \times \cos \varphi \\
& =2.800 \mathrm{w}
\end{aligned}
$$

Daya lampu mneyala dalam 12 jam/hari

$$
\begin{aligned}
P_{\text {hari }} & =P_{\text {total }} \times 12 \mathrm{jam} \\
& =33,600 \mathrm{kWh}
\end{aligned}
$$

Maka konsumsi daya Lampu Penerangan Jalan Umum menggunakan Lampu LED 40 watt solar cell adalah sebesar 33,600 kWh.

\section{Efisiensi}

Setiap dari mesin pasti memiliki batasan ataupun nilai toleransi dimana mesin tersebut bisa beroprasi dengan normal. Pada penelitian yang saya lakukan di jalan raya mantup Kecamatan mantup menggunakan panel surya dengan jenis monocrystalline yang memiliki efisiensi hanya sekitar $15-20 \%$, yang berarti secara mudahnya panel surya hanya dapat mengkonversi sekitar $15 \%$ pada suhu $25^{\circ}$ $\mathrm{C}$, sedangkan efisiensi menurun hingga $15 \%-12 \%$ pada suhu $50^{\circ} \mathrm{C}$.

Maka untuk menghitung nilai efisiensinya dapat di hitung menggunakan persamaan rumus.

$$
\begin{gathered}
\eta=\frac{\text { Pout }}{\text { Pin }}=\frac{\text { Voc } \times I s c \times F F}{S \times F} \\
=\frac{48 \times 3,75 \times 0,76}{1000 \times 0,76} \\
=18 \%
\end{gathered}
$$

Maka dalam perhitungan rumus dia atas mendapatakan nilai efisiensi dari solar cell dengan daya 150 wp adalah sebesar $18 \%$.

\section{Optimalisasisolar cell}

Dari data yang di teliti pada panel surya dengan daya 150 wp mempunyai nilai efisiensi sebesar $18 \%$. Maka untuk meningkatkan efisiensi penel surya dengan cara meningkatkan cahaya matahari, sehingga 
pada panel surya yang terpasang mampu menyerap energi cahaya matahari secara optimal, adalah dengan menggunakan berkonsentrasi optik yang dapat meningkatkan efisiensinya sebesar $15 \%$. Ini merupakan sebuah sistem konsentrator yang dapat meningkatkan intensitas cahaya 6-200 kali matahari. Konversi panel surya terhadap iradiasi memiliki pengaruh besar. Sehingga efisiensi sangat berpengaruh terhadap kualitas daya penerangan jalan umum. apabila tingkat efisiensi pada panel surya tidak memenuhi efisiensi pada pengisian baterai dengan kapasitas yang besar dan daya pemakaian beban yang besar. Maka dari itu tingkat efisiensi panel surya harus diperhatikan untuk menunjang sistem kerja penerangan jalan umum agar maksimal.

\section{Analisa Data}

Pada tabel 4.1 menujukan bahwa pada penel surya ketika pagi tegangan masuk masih $12 \mathrm{v}$, sedangkan pada arus masih 0,1 A. Ketika pada siang hari saat matahari mulai meninggi dan intensitas sinar matahari semakin cerah panel surya dapat menghasilkan teggangan $20 \mathrm{v}$ dan arus $4.0 \mathrm{~A}$. Begitupun juga sebaliknya ketika menjelang sore matahari semakin tegangan dan arus semakin kecil.

Dengan menggunakan panel surya dengan daya 150 wp Pada perhitungan persamaan (4.1) panel surya mampu menghasilkan energi hingga 645,189 wh. Pada baterai dengan kapasitas full/penuh dapat menyalakan lampu hingga 16 jam lebih. Bahkan ketika modul surya tidak mendapatkan cahaya batrai masih mampu mengcover beban hingga 4 jam.

Lampu penerangan jalan di Kecamatan Mantup menggunakan daya 40 watt mengkonsumsi daya sebesar 0,48 kwh dengan insentitas penerangan sebesar 398.1 cd. Dan utuk kuat pencahayaan maksimal menghasilkan 63,2 lux. dengan julah 70 buah lampuh di sepanjang jalan raya Mantup. Jumlah daya yang dipakai dari semua titik lampu adalah 33,600 Kwh dalam satu hari.

\section{PENUTUP}

\section{Kesimpulan}

1. Pada sistem penerangan jalan raya menggunakan solar cell di Kecamatan Mantup Kabupaten Lamongan ketika cuaca dalam keadaan cerah selama satu hari panel surya dapat menghasilkan daya 645,189 wh dan dengan efisiensi sebesar $18 \%$. Jika dalam keadaan panel surya tidak bisa menerima cahaya, baterai masih mempunyai cadangan daya 186 wh. Sedangkan penerangan lampu jalan menghasilkan luminasi maksimal sebesar $15,7 \mathrm{~cd} / \mathrm{m}^{2}$ dan iluminasi maksimal sebesar 63,2 lux. Efisiensi daya dari panel modul solar sel sebesar $18 \%$ ditentukan oleh posisi kemiringan dari panel solar sel dan intensitas cahaya matahari. Semakin tinggi intensitas cahaya matahari semakin tinggi efisiensi keluaran modul solar sel. Sehingga pada jam 12.00 hari tegangan modul meningkat hingga 20 $\mathrm{V}$ sedangkan arus $4.0 \mathrm{~A}$. Pada iklim tropis penerangan jalan menggunakan solar cell sangat cocok sebagai sumber tenaga alternatif.

2. Untuk mengoptimalkan solar cell pada efisensi penel surya adalah dengan cara, pertama memasang sebuah konsentrator optik pada sistem panel solar cell sehingga dapat meningkatkan intensitas cahaya 6-400 kali matahari. Oleh karena itu panel surya yang terpasang dapat menyerap energi cahaya matahari secara optimal. Maka untuk meningkatkan efisiensi solar cell adalah dengan menggunakan konsentrasi optik yang dapat meningkatkan efisiensinya sebesar $15 \%$. Kedua dengan cara apabila tingkat efisiensi pada panel surya tidak memenuhi efisiensi pada pengisian baterai dengan kapasitas yang besar dan daya pemakaian beban yang besar.

\section{DAFTAR PUSTAKA}

Abdul Kadir 2011. Sumber Daya, Inovasi, Tenaga Listrik dan Potensi Ekonomi.UI Press: Indonesia.

Daniel Bimbingan Limbong,Surya Tarmizi Kasim. Perbandingan Teknis Dan Ekonomis Penggunaan Penerangan Jalan Umum Solar Cell Dengan Penerangan Jalan Umum Konvensional. Malang: Universitas Brawijaya

Engga Kusumayogo. Analisis Teknis Dan Ekonomis Penerapan Penerangan Jalan Umum Solar Cell Untuk Kebutuhan Penerangan Di Jalan Tol Darmo Surabaya. Malang: Universitas Brawijaya.

I B Kd Surya Negara. 2016. Analisis Perbandingan Output Daya Listrik Panel Surya Sistem Tracking Dengan Solar Reflector. Universitas Udayana.

Maarebia, Paulus. Instalasi Penerangan Jalan Umum Desa Damau Kabupaten Talaud.

Engineering and Education (E2J) Vol 2, No 3 (2014): E2-J UNIMA. Publisher: Engineering and Education (E2J)

Novianthi, Methi (2010) Studi Pemasangan Instalasi Penerangan Jalan Umum (Studi Kasus) Rusun Cingised Kel. Cisaranten Kulon Kec. Arcamanik Kota Bandung. S1 thesis, Universitas Pendidikan Indonesia.

Renaldo Marsal. Kajian Konservasi Energi Penggantian Lampu Jenis Hps Dengan Led Untuk Penerangan Jalan Umum Kabupaten Banjarnegara. Tembalang: Semarang

Rusman. 2015. Pengaruh Variasi Beban Terhadap Efisiensi Solar Cell Dengan Kapasitas $50 \mathrm{Wp}$. Loktuan Bontang: Politeknik Negeri Samarinda

Sri Kurniati dan Sudirman. 20013. Analisis Efisiensi Keluaran Daya Solar Sel Berdasarkan Sudut 
Kemiringan. Penfui-Kupang, Nusa Tenggara

Timur: Universitas Nusa Cendana. 
